\title{
TOLLE, LEGE!, АБО ДЕ ХОВАСТЬСЯ СЛОВО
}

(рецензія на монографію: Гальчук О. В. «...Не минає міт!»: Античний текст у поетичному просторі украӥнського модернізму 1920 1930-х років: Монографія / Оксана Василівна Гальчук. - Чернівці: Книги - XXI, 2013. -552 c.)

Вислів Андрія Содомори про «живу античність», як і теорема Піфагора чи закон Архімеда, не підлягає спростуванню, ба більше - сприймається як незаперечний факт і навіть трохи «прив'ялий» оксиморон. Можливо, тому книги про нетлінне Слово (адже підживлене міфами й вирощене 3 нього) не викликають ажіотажу, як, скажімо, ті, що епатують, збуджують мозок, дивують своєю «неаксіомністю». Час диктує: модного, нестандартного, вибухового! Класичне стає сьогодні не-форматом, а значить - (майже) не читається, (майже) не продається, (майже) не дискутується... Тому й науковці, котрі обирають для своїх розвідок заздалегідь «неформатний» матеріал, знають, на що йдуть. Що ними керує? Думаю, пристрасть: лише справді зачарована живильною енергією «мертвого слова» (фігуральне означення античності) людина віддає себе на поталу вибагливому часові, адже вкотре повторюване нею: «...Не минає міт!» почує далеко не кожен. Однак, хтось та й почує і - зрадіє, почувши. Я виявилась однією 3 тих, для кого ці слова пролунали. Темно-червона обкладинка книги, де один відтінок переходить в інший, а античні орнаменти в українську етнічну колористику («...червоними і чорними нитками...»), де давньогрецькі й давньоримські міфологічні персонажі оживають на картині українського художника, - ніби стверджують: так, міф не минає, він - живе й гордо крокує у XXI століття (ще один знак: видавництво «Книги - XXI»!). Отож, книга завдяки своїй авторці - Оксані Гальчук - промовляє до мене: «Бери, читай!». Я вже здогадуюся, що слово - оживе.

Оксана Гальчук розпочинає монографію з трактування неоміфологізму, який розгортається в контексті українського модернізму через вектор інтерпретації творів античності «до конотації художніх смислів» (с. 13). Античну художню традицію дослідниця осмислює одночасно i як «доцентрову», і як «відцентрову» площину, як певне «гравітаційне поле» спадкоємності (термін Ю. Султанова), в якому відбувається iї «переплавлення»: переродження, реанімація; античний текст вона розуміє як «парадигму культури взагалі» (термін С. Аверинцева), як текст, що «апелює до духовноініціативного сприйняття його різними поколіннями» (с. 19), як «інтертекст світової, і української літератури зокрема, реципіюючи і трансформуючи який, письменники створюють основу для перетворення власних творів на позначені інтертектуальністю тексти» (с. 34-35), а саме поняття античної прецедентності описує як «динамічний конструкт, що реалізується в нескінченності варіантів, пронизує різні дискурси, впливаючи на всю світову культуру» (с. 22). Саме у дзеркалі діалогу авторка монографії чинить доволі виважену і вдалу спробу осягнути новітні виклики, що стосуються проблем інтерпретації: остання розгортається, за Оксаною Гальчук, у парадигмі «зворотного історизму», де 
«метод imitatio vitae (наслідування життя) доповнився imitation veterum (наслідування старих зразків)» (с. 30). Дослідниця стисло подає історію розвитку концепції вертикального контексту, вдало обгрунтовуючи ії значущість для вивчення давньої греко-римської літератури, адже саме соціально-історичний вертикальний контекст дає змогу письменникові не лише «створити "свій” образ античності, а й алюзивно моделює образ авторової сучасності, у якому синтезуються риси, властиві сучасному і минулому» (с. 39). Філологічний же вертикальний контекст (виявлений у літературному творі різними способами актуалізації асоціативних ланцюгів із прецедентними текстами) слугує «для 3'ясування специфіки різних інтерпретаційних особливостей античного тексту як на рівні індивідуального стилю, так і на рівні загальних тенденцій його засвоєння і трансформації» (с. 40).

У дзеркалі рецепції античного тексту авторка виокремлює основні інтерпретаційні моделі поетичного осмислення «чужого» тексту у власному й античного - в українській поезії 1920-30-х років, як-от: дифузна, символічна, неокласична, неоромантична (с. 41). Залучаючи наукову рецепцію «античності як інтертексту» (с. 42), Оксана Гальчук пропонує власне розуміння термінів «античний сюжет», «античний образ», «античні міфологічні мотиви» (с. 41-45). Базовим комплексом мотивів науковець називає космологічний, до складу якого входять зокрема мотиви про походження світу, антропогонічні та есхатологічні. Доповнюють цей комплекс (за рахунок транспортації нових значень) такі міфологічно-мотивні комплекси, як екзистенційний і естетичний. Оксана Гальчук детально зупиняється також на терміносполуці «українська античність», подаючи палітру наявних дефініцій цього поняття, обгрунтовуючи власне тлумачення даного феномену й акцентуючи на «створенні національного варіанта античного тексту 〈..>, який разом із потужним духовним потенціалом християнства ідентифікує риси Свропи як культурного регіону <...>» (с. 50-51). Дослідниця чітко окреслює етапи історії наукової рецепції української античності: від різнополюсних літературних дискусій 1920-х років (у яких обгрунтовувалась ідея європеїзму та визначалися «культурно-естетичні орієнтири для новітньої української літератури» (с. 52)) через критичне сприйняття античності як інтертексту, «поглинання літературної критики офіційною ідеологічно-міфологічною системою» (с. 53), наслідком чого стало переміщення «корпусу текстів 3 античною інтертекстуальністю на периферію літературного процесу» (с. 53), а з кінця 20-х років - «вилучення творів, позначених античним «слідом», після фізичного знищення та науково-критичної дискредитації іiі авторів» (с. 53), - до реконструкції знань про українську античність та до поліметодологічності іï досліджень (остання пов'язана зокрема 3 актуалізацією 3 кінця ХХ століття досліджень у сфері міфопоетики). При цьому Оксана Гальчук грунтовно й умотивовано обумовлює потребу дослідження української античності, зазначаючи, що «історія рецепції античності - це певною мірою й історія змінності поетичної картини світу, а також метаморфоз, яких зазнала психологія творчості від античності до сьогодення» (с. 55), а саме прочитання античності - це пошук людиною самої себе, ідеалу, шляху пізнання, 
«олюднення» дійсності. Дослідниця описує поетапність імплементації античної складової в художній текст: від використання «декоративно-міфологічної, номенклатурної сторони античності» - через функціональне призначення - до авторського творення міфу за античним зразком (що вважається «вершинним виявом освоєння античності» (с. 57)); зміну форм рецепції античності, яка характеризується зміщенням акцентів, руйнуванням традиційної семантики, переосмисленням домінант прецедентних концептів (с. 57-58). Постмодерністське ж прочитання античних творів (обумовлене специфікою постмодерністського мислення) виявляє ігрові стратегії, ідея яких започатковується ще в античні часи, а культурологічний підхід допомагає побачити накладання античних та християнських підвалин у культурному полі українства (с. 58).

Генезу української античності Оксана Гальчук розглядає в дзеркалі синтезу давньохристиянської й античної координат, наслідування впливів, вищим виявом чого авторка визнає «акт ентелехії, коли дух античності виявляється суголосним темам і образам, які втілюють національну ідею» (с. 109; див. ширше: с. 59-109).

Структуру монографії зумовила класифікація моделей трансформації античного тексту. Так, другий розділ дослідження присвячено художній реалізації дифузної моделі на прикладі творчості Миколи Філянського і Володимира Кобилянського. Аналізуючи рецепцію античності Філянським, Оксана Гальчук сфокусувалася на особливостях авторського прочитання Овідієвих «Метаморфоз»: у збірці «Сalendarium» метаморфози мотивуються не психологічними чи фатальними чинниками (як-от, у тексті-джерелі), а екзистенційними, чітка ж архітектоніка збірки пов'язана 3 низкою формозмістових ознак та 3 «домінантним принципом укладання текстів за добовим та річними циклами» (с. 132). «Calendarium» Миколи Філянського $\epsilon$, за словами науковця, «матрицею дифузної моделі», в якій поєднуються домінанти неоромантизму, символізму та неокласики (с. 132-133). Серед яскравих дослідницьких знахідок авторки монографії щодо дифузної моделі виокремимо такі:

- обгрунтування тривимірності збірки Миколи Філянського «Calendarium», міфологічно-світоглядного сплаву в ній пантеїзму i християнства 3 народнопоетичною домінантою, тяжіння поета до західноєвропейського досвіду через іконописні образи (с. 132-133);

- аналіз символічної складової поезій через тему природи як декорації світогляду (зокрема «замикання» кола осінньої тематики символістськими мотивами туги й суму (с. 134-135));

- віднаходження інтермедійного (музичного) коду віршів міні-циклу «квітень» із «Calendarium» (с. 137) та інтертекстуальних зв'язків текстів М. Філянського з творами української та зарубіжної літератури: Т. Шевченка, С. Кльоновича, Ф. Коппе, П.-Ж. Беранже, Й.-В. Гете (с. 136-138, 144-146);

- трактування варіації Гераклітової сентенції «не можна двічі ввійти в одну річку» у вірші М. Філянського «Не сумуй, що пісня з долу»; образів: хронотопу «там», медіаторів «подорожній» та «перехрестя», що реалізують зокрема мотив 
чужини та виявляють «авторську концепцію поета-медіума у вічному блуканні, проклятого подвійним хрестом земного буття і таланту» (с. 140); мотиву самотності як домінанти «діад і тріад у поезіях М. Філянського філософського й історіософського змісту» (с. 147);

- опис трансформації Філянським Овідієвого обрядового екскурсу в тему втрати історичної пам'яті як складової авторської світоглядної «деградаційної моделі розвитку цивілізації» (с. 141);

- осмислення накладання в етнообразах-флорономенах узвичаєної української символіки з різноманітними формами античної інтертекстуальності (c. 142-143).

Лірику іншого українського поета - Володимира Кобилянського - Оксаною Гальчук розглядає у фокусі орфічних образів (храму, лебедя, сокола, осені, весни, «золотої імортелі», дзеркала, русалки тощо) і мотивів (смутку, втраченого «золотого віку», самовизначення, ранньої смерті, самотності, «неминучого приречення на життєві муки», Нарциса, самопізнання, розлуки, втраченого кохання тощо) через авторські варіації античних міфів про Орфея, Пігмаліона. Оригінальним $\epsilon$ потрактування образу поета-сокола в ліриці В. Кобилянського, котрий вступає у «латентну полеміку з образом митця, якому властиве натхнення як високе, але наївне осягнення дійсності» (с. 153); транценденталістського філософського комплексу «злиття усього в усьому», яким поет «охудожнює епікурейську ідею», «Евріпідівські та Лукіанівські чуття» через образ смерті як однієї з форма буття (с. 156-157); антиномії «душа - думи» як маніфестації різних інструментів пізнання світу: інтуїтивного й раціонального (с. 157); діади «степ - море» як метафор чужини й батьківщини, свободи відповідно (с. 158-159); полісемантичного образу дзеркала («небесного дзеркала» як перевернутого, примарного ідилічного світу (с. 160), «дзеркала душі» як актуалізації мотиву двійника (с. 160)).

Третій розділ монографії присвячено символістській моделі античної інтертекстуальності, на прикладі творів П. Тичини і Д. Загула. Дослідниця виокремлює домінанти художнього освоєння античності Павла Тичини на матеріалі збірки «Сонячні кларнети», серед яких - ідея чути «музику сфер», згідно з якою музика осмислюється поетом як «очищувальна стихія, здатна гармонізувати людське буття» (с. 168-169); вагомість духовного світла, шлях до якого - через пантеїзм й панмузичність (с. 169); маніфестація ірраціонального осяяння світу (через трансформований Тичиною образ однієї 3 Мойр «вишивальниці» долі (с. 170); синтезування й трансформація античної і національної художніх традицій через мотиви (які дослідниця лише зазначає, не уточнюючи); урівноваження прекрасного й героїчного (алюзія Вергілісвого «Праця все переможе») як «варіант латентної опозиції ідеологічного міфу, витвореного за умов нагальної потреби в системі ідейних координат нової історичної епохи» (с. 171); космічно-атомна «оболонка» образу поетагромадянина, що корелює з античними ідеями атомізованого космосу через інтертекстуальні зв'язки з творами Піндара, Лукреція, Піфагора (с. 172), а також гораціанський варіант поета-ментора, що полягає в апології філософії виживання (зокрема через трансформацію узвичаєного образу держави-корабля 
в бурхливому морі на образ надійного човна та образ «обережного наставника, побитого життям і критиками» (С. 172-173)); діонісійське осмислення творчості (через антиномії «річка-став», «старе-нове» та «образів ряду концептів калокагатії - «моральної досконалості та витонченості культурної» (М. Зеров)» (с. 176), символи динаміки, руху); моделювання образу-метафори, в якому увиразнюється авторська інтерпретація недосяжного ідеалу античності (с. 176); гомерівська тематично-образно-віршована складова в поезіях як активне реципіювання античності та ії накладання на авторське бачення політичної та історичної ситуації в Україні на початку 20-х років XX століття (с. 178-179). Саме в контексті гомерівської інтертекстуальності Оксана Гальчук пояснює подальшу трагедію митця, «який, тонко й глибоко розуміючи, щзо відбувається, пізніше свідомо обере гірший, ніж мовчання, варіант - відмову від себе» (с. 179), зокрема у другій строфі вірша «Розкривши Гомера», де на вертикальний контекст накладається горизонтальний (філологічний) рівень (с. 179-180). Оригінальними є інтерпретація дослідницею синергійного образу музи, яку поет потрактовує через візуально-піроморфний код (зоровий образ кукурудзяного качана, яскраво-жовті зерна якого нагадують поетові вогняні іскри» (с. 165); образу анти-Пенелопи (с. 180-181), Пенелопи-України (на противагу «Навсікаї-Росії») (с. 191). Дуже вдалою є побудова Оксаною Гальчук інтертекстуального містка між віршем Тичини «Пругкий початок кукурудзи» i гомерівським визначенням поета-деміурга як співця і коваля (с. 169-170); розкриття порушених у творчості поета проблем, що екстраполюють античні прецеденти на сучасність «як своєрідні поетичні аргументи» (с. 188): смертної кари, вождя-демагога (с. 182-100). Неоміфологічний образ Прометея (і його трансформація «від гармонії до енгармонії і, врешті, до дисгармонії» (с. 189)) стає ключовим у розумінні Оксаною Гальчук метаморфоз Тичини-поета, що призводять до його деградації. (Саме цьому присвячено один із підрозділів монографії (с. 188-213).) Дослідниця описує тичинівську драму-феєрію «Прометей», вірші «Прометей», «Ходить Фауст» i «Слався!» (в яких простежуються метажанрові ознаки) як «частини цілісного тексту 3 характерними для антиутопії ідейно-художніми домінантами» (с. 193), зі стрижневою міфемою «Прометей». Антиутопічна компонента, як зазначає Оксана Гальчук, трапляється зокрема в міфах про золотий вік, який постає у драмі «втіленим у життя технократичним, машинним, математизованим “раєм"» (с. 197). Дослідниця проводить глибокі паралелі між твором українського поета і творами світового письменства: «Ми» С Замятіна, «1984» Дж. Орвелла, «Магомет» Вольтера, доводячи неоміфологізм тексту драми, «план вираження якого здійснюється картинами сучасного життя, а план змісту створюється співвіднесенням зображуваного 3 міфом, що одержує функцію «шифру-коду», прояснюючи сенс того, що відбувається» (с. 202) й описуючи деградацію Прометея, котрий «стає частиною зла, з яким боровся сам. <...> страшною пародією на того, чиє ім'я - знак любові до людей, сміливості духу й поступу» (с. 205-206; див. про це ширше: с. 205-215). Обгрунтованою є думка Оксани Гальчук щодо інтерпретації вірша «Ходить Фауст», у якому «Тичина затавровує не Лже-Фауста <...>, а Лже-Прометея - символа знахабнілого 
плебсу» (с. 209), а сам Фауст «впевнено набуває статусу символу влади системи - умовності» (с. 210).

Інтертекстуальна стратегія Д. Загула реалізується більшою мірою, доводить дослідниця, через комплекси космогонічних, верленівських мотивів, котрі «залучено як упізнавальні знаки» (с. 218) (як-от: втрати, розлуки, скорботи, золотого віку, ностальгії на чужині тощо), зв'язок із українською бароковою (зокрема сковородинівською) практикою (с. 213-237). Оригінальним $\epsilon$ потрактування дослідницею образу митця-деміурга в поезіях раннього Д. Загула: віднаходження в Пігмаліоні - митцеві-ремісникові, митцевіскульпторові - alter ego поета, що є важливішим за сам акт творення (с. 221223), у наслідок якого «мистецький витвір <...> перетворюється на це один всесвіт, у якому віддзеркалюється малий всесвіт автора» (с. 223); трирівневої інтерпретації змісту поезії «Над морем» - культурно-семіотичної орієнтації Д. Загула, котра виявляється через інтертекстуальні посилання (с. 228-229), а також вертикально-горизонтального контексту поеми «Геліополіс», що не обмежується визначенням прецедентного тексту, а «розуміється як реальна взаємодія літературних текстів, авторового світобачення, реалій соціальноісторичної епохи тощо» (с. 233). У контексті діалогу Д. Загула зі Сковородою Оксана Гальчук розкриває сутність «семіотизації третього ступеня» як одну 3 провідних рис української античності ХХ століття (с. 224).

У четвертому розділі монографії, на прикладі поетів «п’ятірного грона» (Микола Зеров, Михайло Драй-Хмара, Максим Рильський, Павло Филипович, Освальд Бургардт), дослідниця вибудовує неокласичну інтертекстуальну модель української античності. Вказуючи на доволі високу міру дослідженості теми античного інтертексту у творах українських поетів 1920-1930-х років, Оксана Гальчук виокремлює в сучасних наукових розвідках ті «точки», що $\epsilon$ вихідними для її власної інтерпретації: так, теза М. Ільницького про творчість зазначених поетів як «мистецьке явище перехідного періоду» розгортається в обгрунтоване твердження, що твори поетів ставали «перетином» інших текстів (с. 243); спостереження Т. Іванюхи наштовхнули дослідницю на виокремлення «спільних для митців античності й українських неокласиків рис» (про них: c. 244). Оксана Гальчук описує джерела знань щодо неокласичного контексту античності: коментування (вирізняючи два його типи (с. 248-252)), епістолярій (с. 252-259). Так, листи О. Білецького до М. Зерова, вважає науковець, «можна визначити як різновид метатексту» (с. 258), а саму античність у творах неокласиків - як «код генетичної трансформації» (с. 261), що присутня у творах експліцитно (через образи-міфеми) й імпліцитно (через мотиви та ідеї) (с. 262270). Напрочуд цікавим видається «ораторсько-викладацький» портрет М. Зерова, який дослідниця відтворює з грамотно розставленими акцентами, лаконічно, глибоко та переконливо (с. 270-275). Різноманітні втілення ораторських традицій, резюмує науковець, «стали вагомим складником інтертекстуальності неокласичного тексту і виявом внутрішньої свободи автора в умовах тотальної несвободи» (с. 275).

Одними 3 найбільш вдалих фрагментів монографії вважаю: дослідження інваріантів образу світу неокласиків, крізь призму античного тексту (с. 275- 
309); втілення ідеї космізму, що розкривається, зокрема в ліриці П. Филиповича через образи океана, коня, Прометея, неба. (Небо, до речі, дослідниця назває «концептом» (с. 287)), у М. Драй-Хмари - через образ України-Геї як «невід'ємної частки одвічного Космосу» (с. 279); ідеї краси-досконалості світу мистецтва (тема творення словом); образу Криму як спадкоємця Давньої Еллади (с. 280); імпресіоністичної моделі світобудови М. Зерова (з образною домінантою - міфологемою дому-космосу, «малого дому», що «уособлює сковородинівський ідеал непорушної гармонії» (с. 281). Оригінальними концептуально й текстуально обгрунтованими $є$ запропоновані дослідницею варіанти образу сучасного світу, осмислені неокласиками через античність:

1) «реалістичний» варіант, представлений зокрема в циклі М. Зерова «Київ і Будівництво» образами храму, Києва як «знака культури, що промовляє про націю крізь віки» (с. 284), у ліриці Ю. Клена - образом Украйни - «Риму, що не здійснив ще історичної місії стати вільною і сильною державою» (с. 291). Оксана Гальчук аналізує інваріанти «проекції реальної дійсності» 3 експлікованими елегійними (с. 285-291) й ідилічними (с. 291-296) домінантами, розкритими авторськими жанрово-стилістичними «матрицями» поетівнеокласиків. Однак, зазначає дослідниця, «в більшості випадків системотвірним фактором виступає не жанрова модель, а індивідуальний стиль неокласика, що, синтезуючи різні традиції, перетворює художній світ на елегійний» (с. 289). Слушною є заувага Оксани Гальчук щодо тяжіння лірики М. Зерова «до поезії еліотівського типу, першою умовою істинності якої $\epsilon$ інтелектуальність і складність, другою - об'єктивність, безособовість» (с. 290);

2) «культурологічний» варіант поетичної проекції сьогодення (зокрема варіативна інтерпретація «образу-згустку загибелі Римської імперії», створений як «символ унаочнення суперечностей сучасного світу i водночас його альтернатива» (с. 299) у поемі Ю. Клена «Попіл імперії»; «пунктирне відтворення» міфологічного сюжету про Адоніса й Афродіту й трансформація протообразів у символи, через які порушуються онтологічні, суспільні та філософські проблеми у віршах М. Рильського (с. 300-303);

3) «альтернативний», «інший» світ, створення якого відбувається на макрой мікрорівнях, таких як культурологічна парадигма та поліфункціональний мотив сну (рівень змісту); трансформація ідилії в елегію (рівень жанру); іронія ліричного героя (інтонаційний рівень) (с. 305). Дослідниця аналізує оніричну систему у творах поетів-неокласиків, акцентуючи на філософській домінанті «моделювання образу світу як фікції» (с. 307): сон стає для них «засобом утвердження ідеї гармонії світу <...>, поети відбивають потребу вийти поза окреслене коло трагізму, абстрагуватись від простору повсякденного» (с. 307; див. ширше: с. 307-310).

В античній парадигмі ліричного героя поезій неокласиків Оксана Гальчук відводить ключову роль образам гомерівської «Одіссеї», головний мотив якої («пошук шляху до покинутої батьківщини» (с. 312)) стає наскрізним у сонетах циклу «Мотиви Одіссеї» М. Зерова (с. 312-317), вірші Ю. Клена «Шляхами Одіссея» (с. 318-320) (в якому, припускає дослідниця, «продемонстрована подвійна рецепція античності»: на сюжетно-образному й ідейному рівнях 
(с. 319-320)); поезії М. Рильського «Як Одіссей, натомлений блуканням...» (у якому соціальний мотив витіснено філософським і інтимним (с. 322 ), а в низці інших поезій - «поступ від діонісійства [зокрема через образи вина, келиха Ю. В.] до аполлонійства, що <...> може сприйматися як рух від хаосу до гармонії» (с. 322), як перетворення «драматичного, позначеного хаотичною стихією досвіду, на джерело нових емоцій і знань» (с. 326), перегуки 3 Анакреонтом, Сапфо через античні мотиви й міфологеми, що виступають «мірилом істинності» (с. 330). У контексті такої трансформації діонісійського в аполлонівське Оксана Гальчук досліджує різноманітні механізми семіотизації: другого ступеня (античний текст осмислюється через присутній у творі М. Рильського «перегук» із секстиною Петрарки) i третього ступеня («розширення поетичного задуму Ф. Петрарки завдяки введенню ліричного героя - alter ego автора» тощо (c. 331-332), а також за допомогою зміщення акцентів (як-от, у вірші «В освяченім гаю»). Особливої ваги в поезії неокласиків, доводить науковець, набирають образи Поета (зокрема через ідіостилістично осмислені міфоніми Орфея, Дедала, Хірона, Пігмаліона), Поезії (зокрема через образ метелика) як складники неокласичної концепції митця $\mathrm{i}$ творчості (с. 334-343). Літературознавець акцентує увагу на особливостях українського варіанту неокласики: «не відстороненість, а активна художня реакція на те, що відбувається, укладена метою «ввести» у світовий культурний простір читача, який вміс розкодовувати розгалужені інтертекстуальні зв'язки їхніх текстів» (с. 343). Оксана Гальчук осмислює також «празький» варіант рецепції античного тексту через призму творчості Є. Маланюка (с. 343-398), вибудовуючи «історіософську модель світогляду поетів «Празької школи»»» (c. 345). Так, дослідниця зазначає, що, «на відміну від ранніх символістів, <...> Є. Маланюк не віддає переваги міфемам i міфічним сюжетам, а творить власний універсальний образ античності, що висотується зі згадок про історичні події, персоналії, культурологічні та географічні поняття тощо» (с. 350) (як-от, образи Трої, Спарти, Атен, Риму, що виступають у поезіях «полісемантичними концептами», у яких поєднуються історичне й міфологічне й демонструють векторну спрямованість з минулого в майбутнє (с. 356)) й розкриває історіософську систему координат $Є$. Маланюка. Цікавою є розвідка авторки стосовно текстових варіантів концепта театру в поезії $С$. Маланюка (с. 356-359). «Вплетення» Маланюком в поему «П'ята симфонія» музичного контрапункту однойменного твору Бетховена дає підстави розглядати зазначену «Симфонію...» як міжтекст, що постає як наслідок зв'язків «текст текст» і «текст - дійсність» (с. 361). Окреслюючи особливості втілення історіософії у творах Є. Маланюка, Оксана Гальчук дискутує з Н. Плахотнік щодо рівнозначності ролі християнського й міфічного античного уявлень про час. Авторка монографії вважає, що вкраплені в поезію «Tertia vigilia» античні елементи «приглушають катастрофізм протетичних мотивів вірша» (с. 363). Слушною, на нашу думку, видається «оптимістично-песимістична» опозиція античної концепції часу християнській: якщо в християнстві «лінійне сприйняття часу» передбачає обов'язковість кінця i початку, то «ідея циклічності й безкінечності, відсутність есхатологічних сюжетів в античній 
міфології» проектує оптимістичний погляд на світ. Саме такий синтез двох комплементарних парадигм в амбівалентному часопросторі історичної доби спостерігається у творчості Є. Маланюка (с. 363-364).

Дослідниця легко і вправно аналізує інтертекстуальнні «містки», за допомогою яких прецедентна античність входить у поезію $С$. Маланюка то заголовками, то епіграфами, то міфологемами, то «відзвуками» інших неоміфологічно осмислених творів: ремінісценціями сюжету, цитатами, мотивами, образами-символами тощо). Так само віртуозно Оксана Гальчук на конкретних текстах розглядає експлікатеми інертекстуальності (серед яких форми стилізації) через «мозаїчність мотивів, філігранність поетики» (с. 371), автохарактеристику ліричного героя, «алегорію поетикальних рядків як когорт гладіаторів» тощо) у творах із висловом-інтертекстом «Ave, Caesar, morituri te salutant». Дослідниця вдається до скрупульозного й глибокого аналізу такої структури, як «текст у тексті»: епіграфів, мотивів (наприклад, мотив тривалих мандрів Одіссея, що символізує буття на чужині та $є$ метафорою сучасного світу у вірші «Присвятні строфи» (с. 374); мотив ініціації, «пов'язаний 3 випробуваннями на вірність переконанням і відданість Батьківщині» (с. 375) у вірші «Так довго був дволикий i двоякий...» тощо). Переконливими $\epsilon$ узагальнення стосовно образів-міфем, у яких відтворюється ідіостильова, маланюкова, комплементарна парадигма: образ Навсікаї - персоніфікованої України, в якому спостерігається «розростання семантики прецедентного персонажа $<\ldots>$ від традиційно-позитивного «ніжне почуття» до «спокуси чужиною» через зіставлення з Пенелопою i, врешті, до політизованого й національно маркованого образу «майбутня держава», що свідчить про «поетапну трансформацію античної міфами <..> від образу-емблеми до концепту авторського історіософського міфу» (с. 375-376).

Аргументацією «злетів і спадів» (В. Моренець) українського модернізму обумовлено, пояснює авторка монографії, виокремлення й дослідження неоромантичної моделі трансформації античності (Розділ V), якій «властива внутрішня суперечливість, зумовлена складними стосунками модерністської й авангардистської систем» (с. 411). Науковець наголошує на двох ключових виявах ранньомодерністської рецепції античності: трансформації міфологічного мотиву «золотого віку» й опрацюванні урбаністичної теми, що в ліриці неоромантиків зрілого періоду зазнають трансформації, відповідно перегукуючись з ідеологемою «світлого майбутнього» в тоталітарному міфі й заміщуючись мотивом «залізного віку» - проекцією «сучасної машинізованої цивілізації» (с. 413), а також набуваючи ознак «органічності та природного динамізму» й асимілюючись із «новонародженою політичною системою» (c. 413-414). Одним із «коригуючих чинників» неоромантичної моделі поетичної інтерпретації української античності Оксана Гальчук називає соцреалізм. Дослідниця аналізує актуалізовані в «новому хронотопі» (соціалістичної доби) моделі космогонії та есхатології, зазначаючи трансформовані міфологічні мотиви (зокрема міфічного майбуття - через міфологему Золотого віку, агонічні мотиви - через протиставлення героя ворога тощо) (с. 428-431), а також трансформовані в ідеологеми міфологеми 
мілітаризму та техніцизму (с. 431-433). Одним із найпомітніших мотивів теми війни й крові у творчості неоромантиків Оксана Гальчук називає мотив братовбивства, що розкривається (особливо в Є. Плужника) «крізь призму національної і загальнолюдської проблематики» (с. 432). Вписаним у «матрицю радянської агіографії» $€$ i образ ліричного героя: в ліриці неоромантиків пізнішого періоду архетип героя оприявнюється в галереї створених «своїх «культурних» героїв» (с. 435) у чітких ієрархічних схемах (с. 436), а також в основному типажі (витвореному шляхом «міфологізування за зразком «культурного» героя i християнського кліше героя-ученика, або шляхом суттєвого редагування прецедентних образів» (с. 436-437)). Поетичний доробок Олекси Влизька дослідниця розглядає крізь призму футуристичного модусу засвоєння й трансформації античності (с. 443-467), а поезію Миколи Бажана та Свгена Плужника - з урахуванням експресіоністичної домінанти в ліриці поетів (c. 467-513).

Післяслово демонструє уміння дослідниці «збирати докупи» й викристалізовувати головне - те, що й формує «діамант» «живої античності». У цілому i в деталях монографія Оксани Гальчук $\epsilon$ філігранним науковим витвором, який хочеться брати до рук і читати. Тому й ти, читачу, tolle, lege!

Юлія Вишницька

Рецензія надійшла до редакиії 21. 12.2015

Прийнято до публікаиії 28.12.2015 